\title{
USE OF FACTORIAL DESIGN TO OPTIMIZE THE EFFICIENCY OF BACTERIAL TRANSFORMATION
}

\author{
GHEORGHITA MENGHIU ${ }^{a, b}$, LAURIANA-EUNICE ZBÎRCEA ${ }^{a, b}$ \\ AND VASILE OSTAFE ${ }^{a, b}$ *
}

\begin{abstract}
A Plackett-Burman factorial design of experiments was created to optimize the protocols of preparation of E. coli DH5a competent cells and transformation of these cells by heat shock method using a chiA_pUC57 plasmid. The numerical parameters to be optimized were: the $\overline{p H}$, the concentration of $\mathrm{CaCl}_{2}$, the cell concentration of the culture used for the preparation of the competent cells, the temperature of defrosting of the competent cells, the concentration of plasmid DNA. It was also considered a qualitative factor that might influence the transformation efficiency, namely the use of ultrasound in the heat shock step of transformation protocol. A design of experiments based on 26 experimental values was created. Analyzing this experimental setup by both, Plackett-Burman factorial design and surface response design, it was highlighted that the $\mathrm{pH}$, the concentration of calcium chloride and the concentration of plasmid DNA have a significant influence on the transformation efficiency. The optimal conditions for the preparation and transformation of $E$. coli DH5a competent cells with chiA_pUC57 plasmid where when the $\mathrm{pH}$ of a $40 \mathrm{mM} \mathrm{CaCl}_{2}$ solution was 6 , the competent stock cells were thawed slowly on ice and in the heat shock step the cells were subjected to ultrasounds treatment.
\end{abstract}

Keywords: design of experiments; Minitab; Plackett-Burman factorial design; surface response design; competent cell; heat shock transformation.

a West University of Timisoara, Faculty of Chemistry, Biology, Geography, Department of Biology - Chemistry, 16 Pestalozzi, 300115 Timisoara, Romania.

b West University of Timisoara, Advanced Environmental Research Laboratory, 4 Oituz, 300086, Timisoara, Romania.

* Corresponding author: vasile.ostafe@e-uvt.ro 


\section{INTRODUCTION}

A common issue encountered in experimental research is when there are several protocols or methods published in scientific journals and all claim to provide the best results. Although the published protocols are reproducible, the results are not as good as it was expected. Another common situation is when in a long list of chemicals and materials used currently in a laboratory protocol one item has to be changed and after that, the expected results are not anymore as they were before. In all these cases, an optimization procedure is recommended to be performed in that lab, using the instruments, chemicals, materials, and so on, that are available at that time. This optimization procedure may be time and other resources consuming unless a design of experiments technique is applied.

The most used method for bacterial transformation is based on the induction of bacterial cell competency by calcium chloride treatment and exposure of bacteria to a heat shock in the stage of plasmid inclusion [1]. This "classical" method of bacterial transformation can provide various degree of transformation efficiency if some of the parameters of the methods are slightly changed. Efficiency of bacterial transformation is influenced by several factors such as concentration of $\mathrm{CaCl}_{2}$ solution [2, 3], plasmids size and plasmid concentration $[4,5]$, heat shock [5-8], optical density of cell cultures (cells concentration) [9], bacterial strain [3], time of cells incubation in $\mathrm{CaCl}_{2}$ solution [10], rotation speed of cells [11] and so on.

The "classical" practice for optimizing an experimental protocol is the one-factor-at-a-time method, i.e. to change in an experimental series only one experimental parameter. There are several options offered by the design of experiments approach, like factorial design, which imply the simultaneous optimization of all the factors at once. In this work, there is presented an example of the use of a Plackett-Burman factorial design and surface response design approaches to optimize the method of bacterial transformation by heat shock in the presence of calcium chloride.

\section{RESULTS AND DISCUSSION}

There are many reasons when an optimization of the experimental procedure has to be performed in a laboratory: introducing a new method or a new version, changing a few of the instruments, reagents or other sources of materials. Instead of using the one-factor-at-a-time strategy, one may save time, money and other resources by selecting a strategy to design the experiment, like the factorial design. In this strategy, there are selected some parameters that are considered to have an influence on the outcomes of the 
experimental procedure and the values of these factors are changed in the same series of experiments. For example, for the transformation of $E$. coli $D H 5 \alpha$ strain with the plasmid pUC57 (that have a gene inserted, in this case, the gene of chitinase (chiA), following the general procedure based on calcium chloride and heat shock, one may consider the following factors: the concentration of calcium chloride solution used to make the competent cells, the $\mathrm{pH}$ of this solutions, the concentration of plasmid DNA (in fact the volume of plasmid DNA used in the transformation procedure, i.e. $0.5,1$ and $2 \mu \mathrm{L}$, respectively), the temperature used to thaw the competent cells preserved at $-80^{\circ} \mathrm{C}$ and the use in the heat shock step of a ultrasonic bath.

In the bacterial transformation process, the calcium chloride plays an important role by the binding of plasmid DNA to lipopolysaccharides from the cell membrane. Positively charged calcium ions attract the negatively charged backbone phosphate groups from DNA molecule. The plasmid DNA can then enter into the cell under heat shock $\left(+42^{\circ} \mathrm{C}\right.$ for a short time). [12] It was shown that when the concentration of calcium chloride is over $200 \mathrm{mM}$ and under $50 \mathrm{mM}$, the bacterial transformation efficiency is minimal [2, 13]. In many protocols for bacterial transformation, calcium chloride concentrations used is $75 \mathrm{mM}$ [11, 14], $100 \mathrm{mM}$ [1, 3, 15-17], $200 \mathrm{mM}$ [10]. Most often, the $\mathrm{pH}$ value of the solution of calcium chloride is not specified. Normally, the $\mathrm{pH}$ of calcium chloride solutions varies between 8.0 and 9.0 as other components, like TRIS, are present. Only in a few transformation protocols, the $\mathrm{pH}$ of $\mathrm{CaCl}_{2}$ solution is specified to be around 7.0 [14].

We also considered two factors whose influence has not been studied so far. The duration of the cell defrost step can be reduced if the cell kept at $-80^{\circ} \mathrm{C}$ are thawed rapidly at $37^{\circ} \mathrm{C}$ instead to slowly thaw them on ice. This is why we have considered the thawing temperature as a factor in the design of the experiments. The other factor considered was the use of an ultrasonic bath (operating frequency $44 \mathrm{KHz}$, ultrasonic power $14 \mathrm{~W} / \mathrm{L}$ ) in the step of the heat shock.

Considering all these numerical and qualitative factors a complex design of experiment (DOE) was realized. For the numerical factors, at least two values (considered as minim and maxim) were selected, and in some cases, intermediate values were added, to see if the variation of the experimental response (i.e. conversion efficiency) depends linearly on the considered factors. Based on these factors, a Placket-Burman type factorial design was created in Minitab software (Table I).

The most intuitive graphical representation of the influence of the considered factors on the transformation efficiency is the Pareto chart of standardized effects (Figure 1). 
In the Pareto chart of standardized effects, the higher is the influence of a factor (independent variable) on the response (dependent) variable, the greater is its value. The chart displays the absolute value of the effects and draws a reference line on the chart. Any effect that extends past this reference line is statistically significant.

Table I. The Plackett-Burman DOE matrix, for four numerical factors and one qualitative factor, with some central values for the numerical factors

\begin{tabular}{|c|c|c|c|c|c|c|}
\hline $\begin{array}{l}\text { Run } \\
\text { Order }\end{array}$ & $\begin{array}{l}\mathrm{CaCl}_{2} \\
\text { conc. } \\
(\mathrm{mM})\end{array}$ & $\begin{array}{c}\mathrm{pH} \\
\text { units }\end{array}$ & $\begin{array}{l}\text { Plasmid } \\
\text { Volume } \\
(\mu \mathrm{L})\end{array}$ & $\begin{array}{c}\text { Thaw } \\
\text { Temperature } \\
\left({ }^{\circ} \mathrm{C}\right)\end{array}$ & $\begin{array}{l}\text { Ultrasonic } \\
\text { Bath }\end{array}$ & 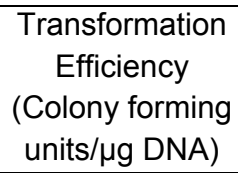 \\
\hline 1 & 80 & 6 & 2 & 0 & No & 76872 \\
\hline 2 & 80 & 8 & 0.5 & 37 & No & 3276 \\
\hline 3 & 40 & 8 & 2 & 0 & Yes & 4187 \\
\hline 4 & 80 & 6 & 2 & 37 & No & 4875 \\
\hline 5 & 80 & 8 & 0.5 & 37 & Yes & 3528 \\
\hline 6 & 80 & 8 & 2 & 0 & Yes & 897 \\
\hline 7 & 40 & 8 & 2 & 37 & No & 3975 \\
\hline 8 & 40 & 6 & 2 & 37 & Yes & 93452 \\
\hline 9 & 40 & 6 & 0.5 & 37 & Yes & 397865 \\
\hline 10 & 80 & 6 & 0.5 & 0 & Yes & 34532 \\
\hline 11 & 40 & 8 & 0.5 & 0 & No & 16785 \\
\hline 12 & 40 & 6 & 0.5 & 0 & No & 421675 \\
\hline 13 & 40 & 7 & 1 & 0 & No & 96167 \\
\hline 14 & 60 & 7 & 1 & 0 & No & 69101 \\
\hline 15 & 80 & 7 & 1 & 0 & No & 8383 \\
\hline 16 & 40 & 6 & 1 & 0 & No & 186047 \\
\hline 17 & 60 & 6 & 1 & 0 & No & 102814 \\
\hline 18 & 80 & 6 & 1 & 0 & No & 15568 \\
\hline 19 & 40 & 8 & 1 & 0 & No & 7964 \\
\hline 20 & 60 & 8 & 1 & 0 & No & 2574 \\
\hline 21 & 80 & 8 & 1 & 0 & No & 1616 \\
\hline 22 & 50 & 7 & 0.5 & 0 & No & 29419 \\
\hline 23 & 50 & 7 & 1 & 0 & No & 16155 \\
\hline 24 & 50 & 7 & 2 & 0 & No & 8604 \\
\hline 25 & 50 & 7 & 1 & 25 & No & 15767 \\
\hline 26 & 50 & 7 & 1 & 37 & No & 15199 \\
\hline
\end{tabular}




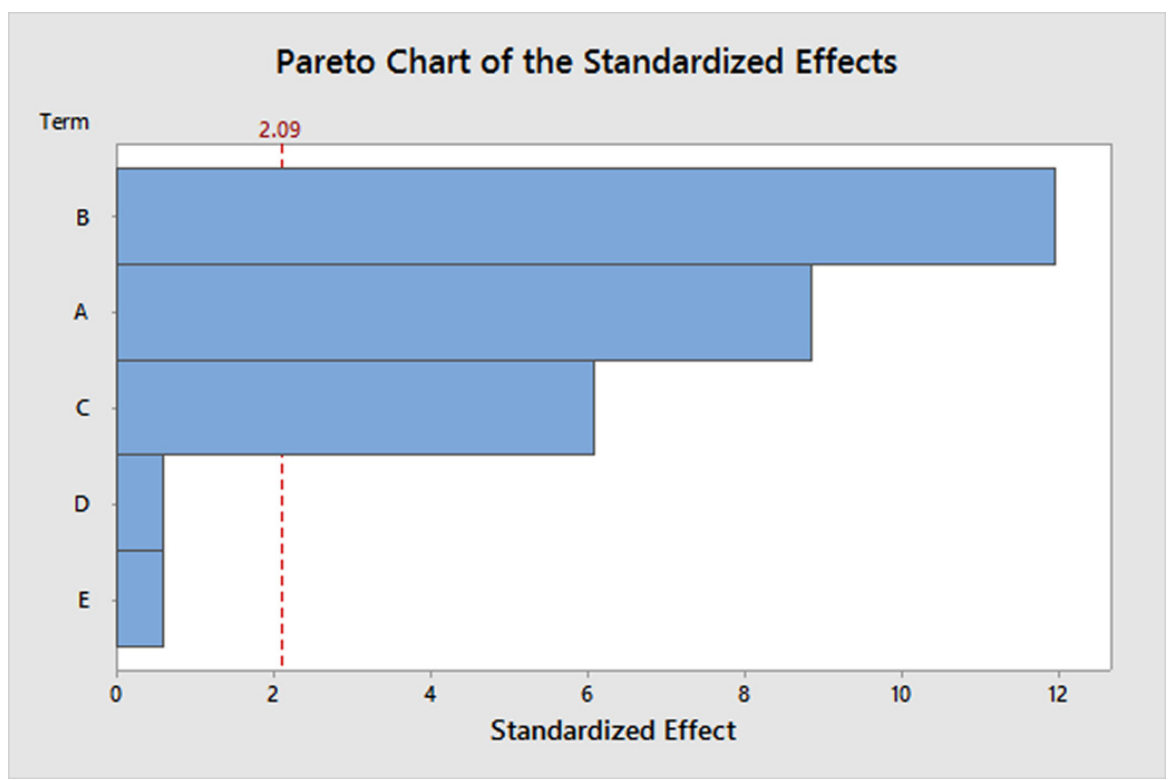

Figure 1. Pareto diagram highlighting the factors that significantly influence the transformation efficiency. Factors: $\mathrm{A}=\mathrm{CaCl}_{2}$ concentration $(\mathrm{mM})$ used to make competent cells, $B=p H$ value of $\mathrm{CaCl}_{2}$ solutions, $\mathrm{C}=$ volume $(\mu \mathrm{L})$ of plasmid DNA solution used in the transformation protocol, $D=$ the temperature in the thawed step of the competent cells kept at $-80^{\circ} \mathrm{C}, \mathrm{E}=$ a qualitative factor, indicating the use (Yes or No) of a ultrasonic bath in the heat shock step. Response is efficiency of transformation at $\alpha=0.05$.

The analysis of the Pareto chart reveals that the most pronounced effect on the efficiency of transformation of $E$. coli cells is due to the $\mathrm{pH}$ value of the calcium chloride solution (factor $\mathrm{B}$ ), followed by effect of the concentration of the $\mathrm{CaCl}_{2}$ solution (factor $\mathrm{A}$ ) and plasmid concentration in the mixture of the reaction (factor $\mathrm{C}$ ). The other factors considered - use of ultrasounds in the membrane labilization stage and temperature of the defrosting step of competent cells have little influence on the transformation efficiency.

The same data were also analyzed using as model a response surface approach. The investigation of the interactions among the factors (Figure 2) shows that between the concentration of calcium chloride and the $\mathrm{pH}$ of this solution is a strong interaction as the variation curves intersect at different angles and the curves have different slopes. This means that their effect is cumulative, modifying the value of a parameter will influence the response function for an initial value of the other parameter. The $x$-axis represents the levels for each factor and the y-axis represents the response. 


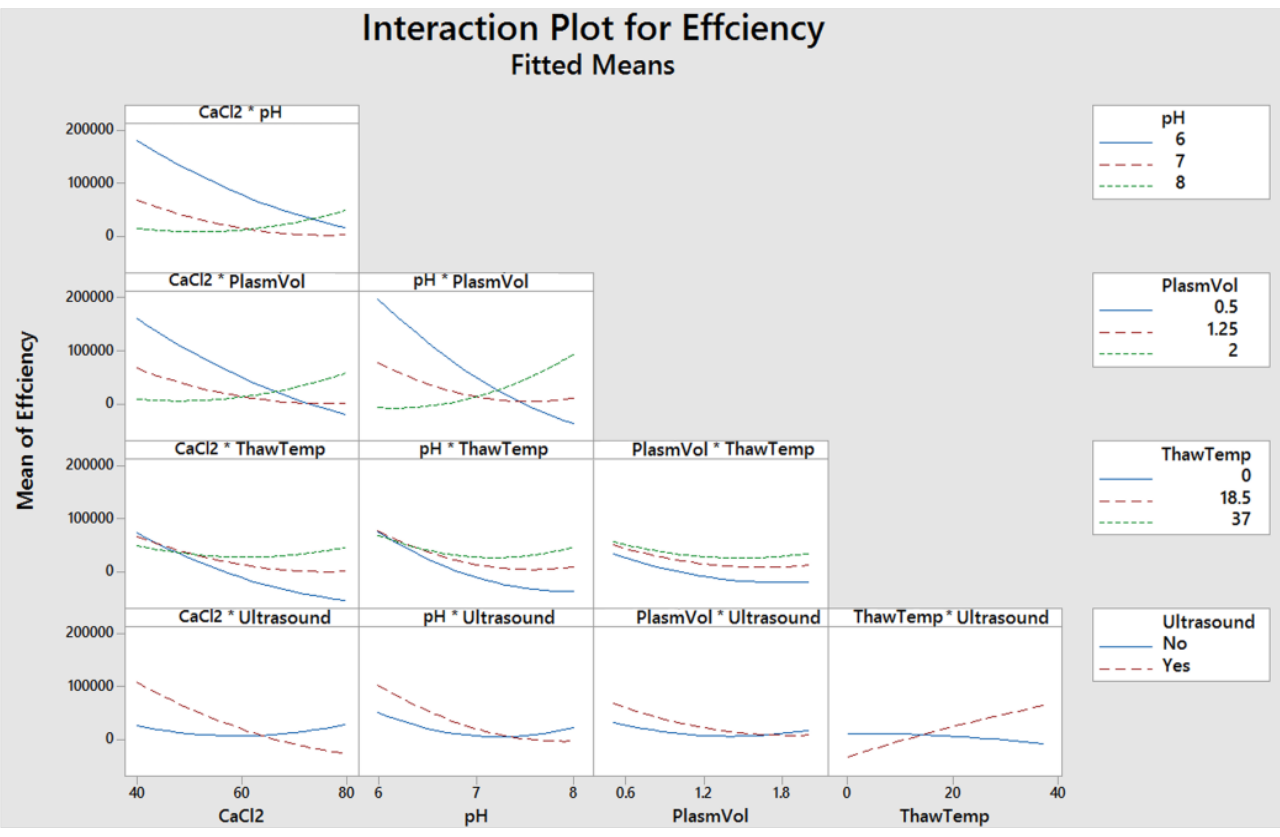

Figure 2. The interaction curves between the factors considered in the study to have an influence on transformation efficiency of E. coli DH5a cells.

Similarly, one may see that there is an interaction between the $\mathrm{pH}$ values of the calcium chloride solution and the plasmid DNA concentration (volume of solution used). On the other side, curves of the thawed temperature of the competent cells do not interact with the other factors, unless, maybe, with the use of ultrasounds in the heat shock stage, but even here the influence is relatively insignificant. In all the cases of the interaction of the thawing temperature with the other parameters, the curves are almost parallel. An analogous situation is in the case of interaction of ultrasound factor with the other parameters, no interaction is revealed as the curves have similar slopes. It is worth to mention that when the competent cells are defrosted slowly, on ice, the use of ultrasounds in the heat shock stage may be justified as it conducts to an increase of the transformation efficiency.

Considering the interaction plots and also other types of graphs that Minitab can provide, and that were not presented here, one may conclude that the optimal conditions for the transformation of $E$. coli DH5a cells with pUC57 plasmid (considering all the experimental details presented in Experimental chapter) are: $40 \mathrm{mM}$ calcium chloride concentration (to prepare the competent cells) having a pH value of 6 , the cells should be defrosted slowly on ice and the use of ultrasounds in the heat shock step is beneficial. 
From that plate that was inoculated with the cell suspension from the vial that fulfills these optimal conditions seven colonies were randomly chosen and grown on liquid selective LB media. The plasmid of these cells was purified by miniprep protocol and subjected to EcoRI digestion. These seven samples were subjected to agarose gel electrophoresis.

\section{Confirmation of the transformation procedure}

In order to prove that the transformed cells obtained in those optimal conditions revealed by the analysis of the interaction curves are indeed transformed, i.e. contain the plasmid chiA_pUC57, seven colonies randomly chosen were verified by subjecting to agarose gel electrophoresis (Figure 3 ) the samples obtained after the purification of the plasmids and their digestion with the EcoRI restriction enzyme.

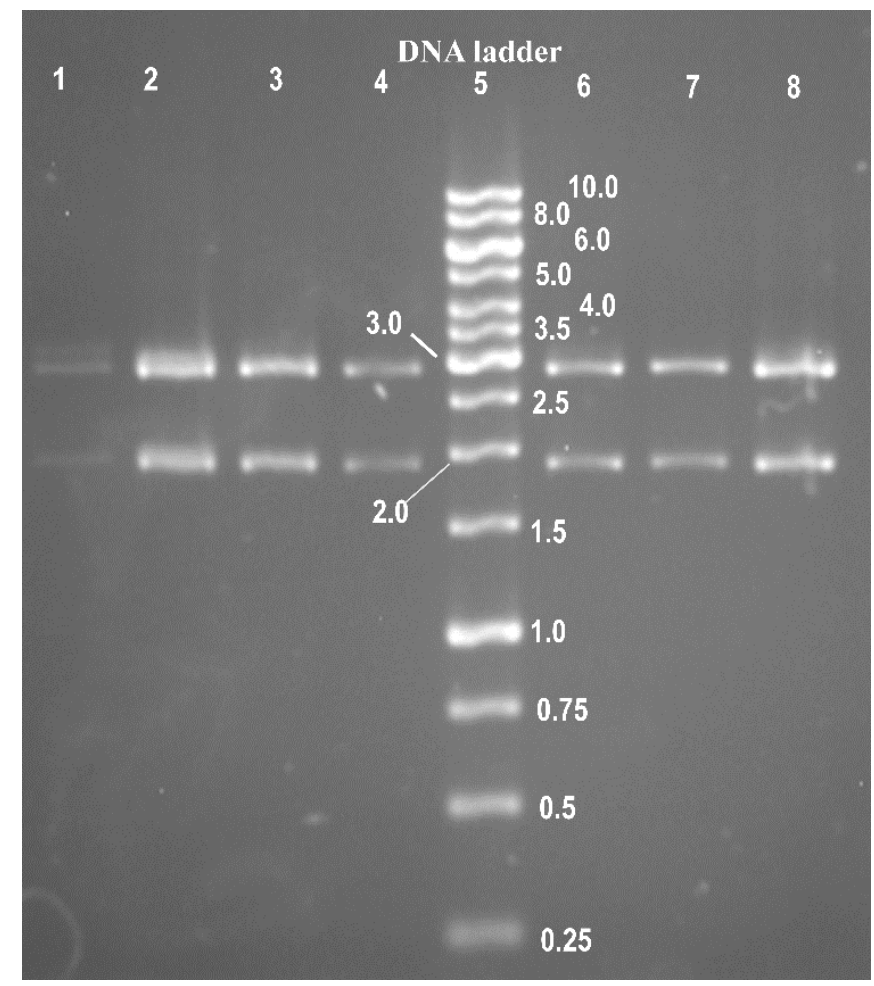

Figure 3. Agarose gel electrophoresis of chiA_pUC57 digestion with EcoRI. The lines 1 to 8 (except line 5 that is DNA ladder, in $\mathrm{kbp}$ ) represent fragments of $2855 \mathrm{bp}$ and respectively $1874 \mathrm{bp}$ obtained after the digestions of the purified plasmids from 7 clones collected from that Petri dish where were cultured the cells transformed in the optimal conditions. 


\section{CONCLUSIONS}

Using 26 experimental values, based on Plackett-Burman and response surface models of design of experiments, there were highlighted the factors that most influence the transformation efficiency of $E$. coli cells, i.e. the $\mathrm{pH}$ and concentration of calcium chloride solution used in the process of preparation of $E$. coli $\mathrm{DH} 5 \alpha$ competent cells and the concentration of plasmid DNA used to transform the competent cells. Both models, factorial and response surface, have indicated that the temperature at which the competent cells are defrosted and the use of ultrasound in the heat shock step do not significantly influence the transformation efficiency.

\section{EXPERIMENTAL SECTION}

\section{Reagents, solutions, and instruments}

\section{Reagents and Enzymes}

The reagents were analytical or molecular biology grade: EcoRI (Thermo Fisher Scientific Inc \#ER0271), yeast extract (Carl Roth, \#2363.3), agar (Carl Roth, \#X928.1), casein hydrolysate (Carl Roth, \#A157.1), NaCl (Carl Roth, \#9265.1), ampicillin sodium salt (Carl Roth, \#K029.2), peptone (Carl Roth, \# 2366.1), $\mathrm{MgCl}_{2}$ (Carl Roth, \# KK36.2), MgSO 4 (Carl Roth, \# P027.2); glucose (Carl Roth, \#HN06.4), EDTA (Ethylenediamine tetra acetic acid)(Carl Roth, \#CN06.3), Tris-HCl (Carl Roth, \#4855.5), sodium hydroxide (Carl Roth, \#6771.3), sodium dodecyl sulfate (SDS) (Carl Roth, \#2326.2), ethanol (Carl Roth, \#P075.3), 2-propanol (Carl Roth, \# AE73.2), DNA loading dye and gene ruler $1 \mathrm{~kb}$ DNA ladder 250 to $10.000 \mathrm{bp}$ kit (Thermo Fisher Scientific Inc, \#R0611), ethidium bromide (Sigma Aldrich, \# 46065).

\section{Culture media, solutions and buffers}

LB liquid media: $0.5 \%(\mathrm{w} / \mathrm{v})$ yeast extract, $0.5 \%(\mathrm{w} / \mathrm{v}) \mathrm{NaCl}, 1 \%(\mathrm{w} / \mathrm{v})$ casein hydrolysate; LB solid media additionally contain $2 \%$ (w/v) agar; SOC media: $0.5 \%(\mathrm{w} / \mathrm{v})$ yeast extract, $0.05 \%(\mathrm{w} / \mathrm{v}) \mathrm{NaCl}, 2 \%(\mathrm{w} / \mathrm{v})$ peptone, $1 \mathrm{M} \mathrm{MgCl}_{2}, 1 \mathrm{M} \mathrm{MgSO}_{4}, 20 \%$ glucose; $\mathrm{CaCl}_{2}$ solution: $40,60,80 \mathrm{mM} \mathrm{CaCl}, 15 \%$ glycerol, $10 \mathrm{mM}$ Tris, $\mathrm{pH}$ 6.0, 7.0, 8.0 (adjusted with $\mathrm{HCl}$ solution); Alkaline lysis solution I (GTE): $50 \mathrm{mM}$ glucose, $25 \mathrm{mM}$ Tris-HCl, 10 mM EDTA, pH 8.0; 100 $\mu \mathrm{g} / \mathrm{mL}$ RNase; Alkaline lysis solution II (P2): 200 $\mathrm{mM}$ sodium hydroxide, $1 \%$ SDS; Alkaline lysis solution III (K-acetate solution): $4 \mathrm{M}$ $\mathrm{CH}_{3} \mathrm{COOK}$; 6X DNA loading dye kit (10 mM Tris- $\mathrm{HCl}(\mathrm{pH} 7.6), 0.03 \%$ bromophenol blue, $0.03 \%$ xylene cyanol FF, $60 \%$ glycerol, $60 \mathrm{mM}$ EDTA) [18].

\section{Strains and plasmids}

The experiments were performed with Escherichia coli DH5a strain for transformation, kindly donated by Fraunhofer IME, Germany [19]. The exogenous recombinant DNA taken in experimental working was a chiA_pUC57 plasmid, which was purchased from Gene Script (\#SD1176). 


\section{Instruments}

Water bath (Julabo MA-4 Heating Circulator, \# 9153504), Ultrasonic water bath operating at $44 \mathrm{KHz}$, ultrasonic power $14 \mathrm{~W} / \mathrm{L}$ (Barnstead/Lab-Line, Aqua Wave 9375, \#034737037) Nanophotometer (IMPLEN P300, \# DI-2110), UV Transilluminator (Vilber Lourmat, \# Z363782), DNA Electrophoresis (SCIE-PLAS HU 6 Mini, \# N562.1), Microcentrifuge (Hettich Mikro 22 R, \# D-78532), Centrifuge (Hettich Universal 320R, \# 1401).

\section{E. coli DH5a competent cells preparation \\ E. coli DH5 growth conditions}

An aliquot from the glycerol stock of $E$. coli DH5a cells was taken with a loop and zigzag scattered on an LB agar plate. The plate was incubated overnight at $37^{\circ} \mathrm{C}$. One colony from the plate was inoculated in $3 \mathrm{~mL} L B$ and incubated overnight at $37^{\circ} \mathrm{C}$ and $250 \mathrm{rpm}$. From the overnight culture, $1 \mathrm{~mL}$ was inoculated in $100 \mathrm{~mL}$ LB media and incubated at $37^{\circ} \mathrm{C}$ and $250 \mathrm{rpm}$ until OD $620 \mathrm{~nm}$ reached at 0.3-0.4 a.u. [20]

\section{Preparation of competent cells with different concentration of $\mathrm{CaCl}_{2}$ and $\mathrm{pH}$}

The $100 \mathrm{~mL}$ culture was divided into nine Falcon tubes and kept on ice for 10 minutes. The cells were centrifuged for $10 \mathrm{~min}$ at $3000 \mathrm{rpm}$. The collected cells were washed two times in $10 \mathrm{~mL}$ ice-cold $\mathrm{CaCl}_{2}$ solution at different concentrations $(40,60,80 \mathrm{mM})$ and $\mathrm{pH}(6.0,7.0,8.0)$ and centrifuged at $3000 \mathrm{rpm}$ for 5 minutes. After the last centrifugation, the cells were kept on ice for 30 minutes and in each vial was added $1 \mathrm{~mL}$ of $\mathrm{CaCl}_{2}$ solution having different concentrations and $\mathrm{pH}$ values. From each of these cell suspensions, portions of $100 \mu \mathrm{L}$ were pipetted in sterile Eppendorf tubes and frozen at $-80^{\circ} \mathrm{C}$ [21].

\section{Calcium chloride transformation of E. coli DH5}

From a stock solution containing chiA_pUC57 plasmid at $2.228 \mu \mathrm{g} / \mu \mathrm{L}$, portions of $0.5,1$ or $2 \mu \mathrm{L}$ were added at aliquots of $100 \mu \mathrm{L}$ of competent cells prepared, as described above, at different $\mathrm{pH}$ values $(6 ; 7$ and 8$)$ and different calcium chloride concentrations $(40,60$ and $80 \mathrm{mM})$. The cell suspensions were kept on ice for 30 minutes. In the next step, the competent cells were exposed to heat shock at $42^{\circ} \mathrm{C}$ for 45 seconds and after that, the cells were incubated on ice for 2 minutes. To the transformation mixtures, portions of $1 \mathrm{~mL}$ of SOC media were added. After $1 \mathrm{~h}$ of incubation at $37^{\circ} \mathrm{C}, 100 \mu \mathrm{L}$ of transformed cells were plated on LB selective media. The plates where incubated around 22 hours at $37^{\circ} \mathrm{C}$. The colonies were counted after 10 hours of incubation until 22 hours of incubation [12].

\section{Transformation efficiency calculation}

The transformation efficiency represents the number of transformed cells (number of colonies) per amount $(\mu \mathrm{g})$ of plasmid DNA spread on a plate [22].

\section{Confirmation of the transformation procedure}

\section{Growth conditions}

Several colonies of E. coli DH5a cells transformed with chiA_pUC57 plasmid were transferred in different Falcon tubes containing $3 \mathrm{~mL}$ selective LB liquid media with ampicillin $(100 \mu \mathrm{g} / \mathrm{mL}$ final concentration). The tubes were incubated overnight at $37^{\circ} \mathrm{C}, 250 \mathrm{rpm}$. DNA plasmid isolation was performed from overnight culture [23]. 


\section{Isolation of chiA-pUC57 plasmid (Miniprep)}

The overnight liquid culture was transferred to a centrifuge tube and centrifuged for $1 \mathrm{~min}$ at 13,000 rpm. The chiA_pUC57 plasmids were isolated using the alkaline lysis method [25] by a series washes with GTE $(150 \mu \mathrm{L}), \mathrm{P} 2(300 \mu \mathrm{L})$, K-acetate $(450 \mu \mathrm{L})$, isopropanol and $75 \%$ ethanol solutions and centrifugation at $13,000 \mathrm{rpm}$. Plasmids harvested by centrifugation were dried by incubation at $45^{\circ} \mathrm{C}$ for 30 minutes. The dried plasmids were dissolved in sterile distilled water and their concentration was calculated based on their optical density at $260 \mathrm{~nm}$. Different concentrations of plasmid were considered for plasmid restriction digestion [24].

\section{Plasmid restriction digests}

The plasmid DNA was cut with EcoRI restriction enzyme. All of the ingredients in a restriction digest mixture were kept on ice until the reaction was started. Restriction digest started by mixing of the plasmid solution $(4 \mu \mathrm{L}$ of DNA plasmid at a concentration between 1 and $3 \mu \mathrm{g} / \mu \mathrm{L})$ with EcoRI restriction enzyme $(0.5 \mu \mathrm{L}, 10 \mathrm{U} / \mu \mathrm{L})$ and with 10X EcoRI buffer $(1 \mu \mathrm{L})$. The ingredients were mixed in the reaction tube and the tube was incubated at $37^{\circ} \mathrm{C}$ for 2 hours. To stop the digestion reaction, the mixture was incubated at $65^{\circ} \mathrm{C}$ for 20 minutes. Once the restriction digest was completed, the digested fragments were separated by size performing an agarose gel electrophoresis [22].

\section{DNA agarose gel electrophoresis.}

For agarose gel electrophoresis, $5 \mu \mathrm{L}$ of restriction mixture mixed with $1 \mu \mathrm{L}$ 6X DNA loading dye were used. To estimate the size of the separated DNA fragments, a gene ladder was used on a distinct line. The agarose gel concentration of $1 \%$ was prepared in 1xTAE buffer. The following parameters were established for the agarose gel electrophoresis: The electrophoretic separation was run at $80 \mathrm{~V}, 200 \mathrm{~mA}, 300 \mathrm{~W}$ for 45 min. When the process was completed, the agarose gel was transferred in ethidium bromide solution $(0.5 \mu \mathrm{g} / \mathrm{mL})$ for $10 \mathrm{~min}$ and visualized under UV light.

\section{The design of experiments}

The designs of these experiments were realized using Minitab software (Minitab Inc., State College, PA, USA). The experimental designs try to explore the dependence of some measured value on a number of independent parameters (factors), each taking value, in such a way as to minimize the variance of the estimates of these dependencies using a limited number of experiments [26]. Plackett-Burman designs (Screening design) allow fractionation of the full factorial design, giving numbers of parameter combinations that are a multiple of four. Response Surface designs are useful for building a model for the response variable without needing to use a complete three-level factorial experiment. The response dependent variable was transformation efficiency. Four numerical parameters and one qualitative were considered. The numerical parameters were the $\mathrm{pH}$ and the concentration of the calcium chloride solution used in the preparation of competent cells, the temperature of defrosting the stock of the competent cells kept at $-80^{\circ} \mathrm{C}$, and the volume of plasmid DNA solution (in fact the concentration of plasmid DNA). The qualitative factor was the use of an ultrasonic bath in the stage of heats shock in the transformation procedure. The matrix of the design of experiments consisted of 26 experimental values and the results were analyzed by both Plackett-Burman factorial design and response surface design. 


\section{ACKNOWLEDGMENTS}

G. Menghiu acknowledges that this work was supported by the strategic grant POSDRU/159/1.5/S/137750, Project "Doctoral and Postdoctoral programs support for increased competitiveness in Exact Sciences research". The authors also acknowledge the GRANT PNIII-P3-284, ChitoWound - Biotechnological tools implementation for new wound healing applications of byproducts from the crustacean seafood processing industry.

\section{REFERENCES}

1. Chan, W.T., C.S. Verma, D.P. Lane, and S.K. Gan, Bioscience Rep, 2013, 33, e00086.

2. Lim, G., D. Lum, B. Ng, and C. Sam, J Exp Microbiol Immunol, 2015, 19, 1-6.

3. Liu, X., L. Liu, Y. Wang, X. Wang, Y. Ma, and Y. Li, Pak J Pharm Sci, 2014, 27, 679-684.

4. Chan, V., L.F. Dreolini, K.A. Flintoff, S.J. Lloyd, and A.A. Mattenley, J Exp Microbiol Immunol, 2002, 2, 207-223.

5. Campos-Guillen, J., F. Fernandez, X. Pastrana, and A.M. Loske, Ultrasound Med Biol, 2012, 38, 1078-1084.

6. Morimoto, R.I., Cancer Cell, 1991, 3, 295-301.

7. Divya Prakash, G., R.V. Anish, G. Jagadeesh, and D. Chakravortty, Anal Biochem, 2011, 419, 292-301.

8. Van der Rest, M.E., C. Lange, and D. Molenaar, Appl Microbiol Biotechnol, 1999, 52, 541-545.

9. Tang, X., Y. Nakata, H.-O. Li, M. Zhang, H. Gao, A. Fujita, O. Sakatsume, T. Ohta, and K. Yokoyama, Nucleic Acids Res, 1994, 22, 2857-2858.

10. Rudchenko, O.N., N.A. Likhacheva, N.V. Timakova, and B.N. Il'iashenko, Genetika, 1975, 11, 101-1019.

11. Li, X., X. Sui, Y. Zhang, Y. Sun, Y. Zhao, Y. Zhai, and Q.Y. Wang, Afr J Biotechnol, 2010, 9, 8549-8554.

12. Dagert, M. and S.D. Ehrlich, Gene, 1979, 6, 23-28.

13. Loske, A.M., J. Campos-Guillen, F. Fernandez, and E. Castano-Tostado, Ultrasound Med Biol, 2011, 37, 502-510.

14. Zhiming, T., H. Guangyuan, X.L. Kexiu, J.C. Mingjie, C. Junli, C. Ling, Y. Qing, P.L. Dongping, Y. Huan, S. Jiantao, and W. Xuqian, Electron J Biotechnol, 2005, 8, 114-120.

15. Maeda, S., A. Sawamura, and A. Matsuda, FEMS Microbiol Lett, 2004, 236, 61-64.

16. Xiaofeng, L., L. Lin, W. Yonggang, W. Xiaoli, M. Yanling, and L. Yunchun, J Chem Pharm Res, 2013, 12, 450-453.

17. Chan, J., C. Davis, and I. Jokic, J Exp Microbiol Immunol, 2006, 9, 92-96. 
18. Liou, J.T., B.H. Shieh, S.W. Chen, and C. Li, Prep Biochem Biotechnol, 1999, 29 , 49-54.

19. Blazic, M., G. Kovacevic, O. Prodanovic, R. Ostafe, M. Gavrovic-Jankulovic, R. Fischer, and R. Prodanovic, Protein Expres Purif, 2013, 89, 175-180.

20. Zhou, A., X. Jiang, and X. Xu, BioTechniques, 1997, 23, 592-594.

21. Aich, P., M. Patra, A.K. Chatterjee, S.S. Roy, and T. Basu, Protein J, 2012, 31, 366-373.

22. Green, R. and E.J. Rogers, Transformation of chemically competent $E$. coli, in Methods in Enzymology, J. Lorsch, Academic Press: New York, United States, 2013, Volume 529, 28, p. 329-336.

23. Carstens, M., M.A. Vivier, and I.S. Pretorius, Transgenic Res, 2003, 12, 497-508.

24. Stephen, D., C. Jones, and J.P. Schofield, Nucleic Acids Res, 1990, 18, 74637464.

25. O'Sullivan D, J. and T.R. Klaenhammer, Appl Environ Microbiol, 1993, 59, 27302733.

26. Carro, N., I. Garcia, M. Ignacio, and A. Mouteira, Anal Lett, 2012, 45, 2161-2175. 